\title{
Evaluation of Humic Acid Application Methods for Yield and Yield Components of Mungbean
}

\author{
Muhammad Waqas',2,3, Bashir Ahmad'2, Muhammad Arif', Fazal Munsif', \\ Abdul Latif Khan1,4, Muhammad Amin'5, Sang-Mo Kang1, Yoon-Ha Kim ${ }^{1,6}$, In-Jung Lee ${ }^{*}$ \\ ${ }^{1}$ School of Applied Biosciences, Kyungpook National University, Daegu, Republic of Korea \\ ${ }^{2}$ Department of Agronomy, Khyber Pakhtunkhwa Agricultural University, Peshawar, Pakistan \\ ${ }^{2}$ Department of Agronomy, Khyber Pakhtunkhwa Agricultural University, AMK Campus, Mardan, Pakistan \\ ${ }^{3}$ Department of Agriculture Extension, Buner, khyber Pakhtunkhwa, Pakistan \\ ${ }^{4}$ Department of Biological Sciences and Chemistry, University of Nizwa, Nizwa, Oman \\ ${ }^{5}$ Department of Agriculture Mechanization, Khyber Pakhtunkhwa Agricultural University, Peshawar, Pakistan \\ ${ }^{6}$ Division of Plant Sciences and National Center for Soybean Biotechnology (NCSB), University of Missouri, \\ Columbia, USA \\ Email: ${ }^{*}$ ijlee@knu.ac.kr
}

Received 23 April 2014; revised 12 June 2014; accepted 1 July 2014

Copyright (C) 2014 by authors and Scientific Research Publishing Inc.

This work is licensed under the Creative Commons Attribution International License (CC BY).

http://creativecommons.org/licenses/by/4.0/

c) (i) Open Access

\begin{abstract}
A triplicate field experiment laid out in randomized complete block design was conducted to evaluate different humic acid (HA) application methods at Agricultural Research Farm, of KPK Agricultural University, Peshawar. Three methods of HA application: seed priming, foliar spray and soil application were included in the experiment. Humic acid application methods significantly affected pods plant ${ }^{-1}$, grains pod $^{-1}, 1000$ grain weights, and grain yield whereas biological yield was not significantly affected by HA application methods. Humic acid application at the rate of 3 kg.ha-1 resulted in higher number of pods plant ${ }^{-1}$, thousand grain weights and grain yield, howev-

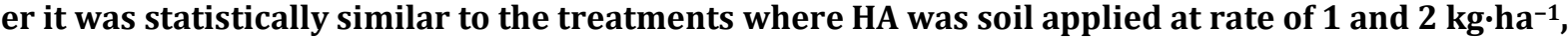
seed priming with $0 \%$ (water soaked), $1 \%, 2 \%$ HA solution and foliar spray with $0.01 \%, 0.05 \%$ and $0.1 \%$ of $\mathrm{HA}$ solution. It is concluded that $\mathrm{HA}$ application in all the three methods significantly enhances grain yield and yield components of mungbean.
\end{abstract}

\section{Keywords}

Mungbean, Humic Acid, Seed Priming, Foliar Spray, Soil Application, Yield

\footnotetext{
${ }^{*}$ Corresponding author.
}

How to cite this paper: Waqas, M., Ahmad, B., Arif, M., Munsif, F., Khan, A.L., Amin, M., Kang, S.-M., Kim, Y.-H. and Lee, I.-J. (2014) Evaluation of Humic Acid Application Methods for Yield and Yield Components of Mungbean. American Journal of Plant Sciences, 5, 2269-2276. http://dx.doi.org/10.4236/ajps.2014.515241 


\section{Introduction}

Mungbean (Vigna radiata (L.), Wilczek) is an important source of protein and has been grown in the Indo-Pak subcontinent since ancient times, where the diet is mostly cereal-based [1]. It is grown mainly for its edible seeds, which are cooked, fermented, roasted, sprouted, or milled. Mungbean seeds, like other pulses, are split and then cooked as a curry called "Dal". Mungbean is also used in making soups, noodles, bread, and sweets; the seeds roasted with spices are also very popular [2]. In South Asia, improved varieties of mungbean are grown on an area of 3 million hectares with a total annual production of 3.1 million tones both under rainfed and irrigated conditions. As a result, mungbean consumption in most of the low income countries has increased from $22 \%$ - 66\% [3]. Despite all these achievements, yields for the rainfed area are generally low and variable due to sparse, erratic rainfall and marginal soils.

Humic acid (HA) is a vital constituent and an intimate part of soil organic structure. It has been used by many scientists, agronomists and farmers for improving soil conditions and plant growth [4] [5]. In plants, humic acids have positive effects on enzyme activity, plant nutrients, and growth stimulant and are considered as a "plant food". Humates are most responsive in high carbohydrate crops like potato, carrot, maize, rice, wheat, etc. [4] [6]. Humic acid contains $51 \%$ to $57 \% \mathrm{C}, 4 \%$ to $6 \% \mathrm{~N}$ and $0.2 \%$ to $1 \% \mathrm{P}$ and other micronutrients in minute amounts. Application of $1.0 \mathrm{~kg} \cdot \mathrm{ha} \cdot \mathrm{ha}^{-1}$ to the soil can bring appreciable increase (up to 20\%) in yields of wheat, maize, cotton, sugar beet and groundnut and improvement in soil physico-chemical conditions [7] [8]. Application of such minute amounts of HA suggests its enzymatic characteristics. Treating seeds with HA may further increase its beneficial effects to enhance crop yield [9].

There are usually three main methods of applying micronutrients to crops: soil fertilization, foliar sprays and seed treatment. Foliar application of micro-nutrients are effective [10] [11], but this method is too costly to be widely practiced by resource-poor farmers in some regions because of the amount of fertilizer, equipment and labor required for repeated spraying. Likewise, the difficulty in obtaining high quality micro-nutrient fertilizers and spreading them evenly on the soil can be unaffordable. Treating seeds with micronutrients potentially provides a simple inexpensive method for improving micronutrient plant nutrition [12]-[14].

To take the advantage of the facts that HA offers great promise for agricultural utilization, this research study was initiated to evaluate different methods of HA application for enhancing yield and yield components of mungbean.

\section{Materials and Methods}

\subsection{Experimental Site}

Peshawar has a warm to hot, semi-arid, sub-tropical, continental climate with mean annual rainfall of about 360 mm. Summer (May-Sep) has a mean maximum temperature of $40^{\circ} \mathrm{C}$ and mean minimum temperature of $25^{\circ} \mathrm{C}$. Winter (December to the end of March) has mean minimum temperature of $4^{\circ} \mathrm{C}$ and a maximum of $18.4^{\circ} \mathrm{C}$. The average winter rainfall is higher than that of summer. The highest winter rainfall has been recorded in March, while the highest summer rainfall is in August. Soil of the experimental site is deficient in N, P and available Zn, but has adequate K. Canal water is available for irrigation [15]. The soil physico-chemical conditions of the experimental site is sand $8.7 \%$, silt $51.3 \%$, clay $40.0 \%$ (textural class; silty clay loam), organic matter $0.845 \mathrm{~g} \cdot \mathrm{kg}^{-1}$, total $\mathrm{N} 0.04 \mathrm{~g} \cdot \mathrm{kg}^{-1}, \mathrm{CaCO}_{3} 14.4 \%$, pH 1:1 water 8.02, electrical conductivity dS $\cdot \mathrm{m}^{-1} 0.87$, AB-DTPA extractible nutrients P (3.80 mg $\left.\mathrm{kg}^{-1}\right), \mathrm{K}\left(105 \mathrm{mg} \cdot \mathrm{kg}^{-1}\right), \mathrm{Zn}\left(0.86 \mathrm{mg} \cdot \mathrm{kg}^{-1}\right)$ [16] [17].

\subsection{Experimental Description}

The experiment was conducted at Agricultural Research Farm of Khyber Pakhtunkhwa Agricultural University, Peshawar $\left(34^{\circ} 01^{\prime} \mathrm{N}\right.$ latitude, $71^{\circ} 35^{\prime} \mathrm{E}$ longitude) during summer 2007 . The experiment was laid out in randomized complete block design with three replications. A basal dose of $60 \mathrm{Kg} \cdot \mathrm{P} \cdot \mathrm{ha}^{-1}$ was applied at sowing time. A starter dose of $25 \mathrm{~kg} \mathrm{~N} \mathrm{ha}^{-1}$ was applied at first irrigation. The seed of mungbean variety NM-92 at the rate of $25 \mathrm{~kg} \cdot \mathrm{ha}^{-1}$ was sown in a plot size of $4 \mathrm{~m}$ by $5 \mathrm{~m}$, having 8 rows of $4 \mathrm{~m}$ length at row to row distance of $50 \mathrm{~cm}$. Mungbean variety NM-92 was developed by hybridization between indigenous mutant line NM-36 and exotic Asian Vegetable Research and Development Center (AVRDC) germplasm accession number VC 2768B at Nuclear Institute for Agriculture and Biology (NIAB), Faisalabad, Pakistan and released after approval in 1996 for general cultivation [18]. The lignitic coal derived HA was purchased from the indigenous humic acid pro- 
duction unite (Department of Soil and Environmental Sciences, Khyber Pakhtunkhwa Agriculture University, Peshawar). Seed of mungbean was primed in different concentration of HA solutions i.e., (0.5\%, $1 \%, 1.5 \%, 2 \%)$ for 8 hours. After priming, the seed was rinsed with tap water and air dried for about 2 hours to avoid sticking of seed with hands at sowing time. For soil application HA was applied at the rate of 1,2 and $3 \mathrm{~kg} \cdot \mathrm{ha}^{-1}$ at the time of seedbed preparation. For foliar spray, solutions of HA $(0.01 \%, 0.05 \%, 0.1 \%)$ were sprayed at 5 - 6 leaf stages of mungbean. The agronomic practices i.e., irrigation, weeding and hoeing etc. were carried out uniformly for all treatments.

\section{The treatments structure as under:}

T1: Dry seed (control), T2: Seed soaking in water, T3: Seed priming in 0.5\% HA solution, T4: Seed priming in 1\% HA solution, T5: Seed priming in 1.5\% HA solution, T6: Seed priming in 2\% HA solution, T7: Soil application of HA@1 kg·ha ${ }^{-1}$, T8: Soil application of HA @ $2 \mathrm{~kg} \cdot \mathrm{ha}^{-1}$, T9: Soil application of HA @ $3 \mathrm{~kg} \cdot \mathrm{ha}^{-1}$, T10:Foliar application of 0.01\% HA solution, T11: Foliar application of 0.05\% HA solution and T12: Foliar application of $0.1 \%$ HA solution.

Data were recorded on pods/plant, grains/pod, thousand grain weights (g), biological yield $\left(\mathrm{kg} \cdot \mathrm{ha}^{-1}\right)$, grain yield $\left(\mathrm{kg} \cdot \mathrm{ha}^{-1}\right)$ and harvest index (\%). Data on number of pods plant ${ }^{-1}$ were recorded by randomly selected ten plants in each plot and their pods were counted and then averaged. To record number of grains pod ${ }^{-1}$, grains of ten randomly selected pods in each plot were counted and then their average was worked out. For thousand grain weights' data, a random sample of thousand grains was taken from the grain yield of each plot and then weighed with an electronic balance. In case of biological and grain yields data, four representative rows were harvested at their maturity from each plot, tied into bundles separately. The bundles were sun dried and weighed by spring balance for calculating biological yield $\left(\mathrm{kg} \cdot \mathrm{ha}^{-1}\right)$. For grain yield $\left(\mathrm{kg} \cdot \mathrm{ha}^{-1}\right)$, their pods were removed from the harvested plants, dried, threshed and weighed with the help of an electronic balance.

\subsection{Statistical Analysis}

The data recorded were analyzed statistically using analysis of variance techniques appropriate for randomized complete block design. For analysis excel worksheet was programmed. Means were compared using LSD test at 0.05 level of probability, when the $p$-values were significant. Five single degree of freedom contrasts were used to make comparison among the application methods and control with rest of the treatments [19].

\section{Results and Discussion}

\subsection{Pods Plant ${ }^{-1}$}

Data regarding pods plant ${ }^{-1}$ are shown in Table 1 . Analysis of the data revealed that pods plant ${ }^{-1}$ was significantly affected by HA application methods. Soil application of HA at the rate of $3 \mathrm{~kg} \cdot \mathrm{ha}^{-1}$ resulted in maximum number of pods plant ${ }^{-1}$, followed by foliar spray each of $0.05 \%$ and $0.1 \%$ of HA solution which were at par with one another. Minimum pods plant ${ }^{-1}$ were noted for dry seed.

Planned mean comparison indicated that the differences between control vs. rest, control vs. water soaked, seed priming vs. foliar spray and seed priming vs. soil application were significant for pods plant ${ }^{-1}$, while the difference between foliar spray vs. soil application was not significant (Table 2). Dry seed produced lower number of pods plant ${ }^{-1}$ as compared to the mean of rest of the treatments and water soaked seed. Seed priming produced lesser number of pods plant ${ }^{-1}$ as compared to soil application and foliar spray. Here the resultant higher number of pods due to soil application of HA can be correlated with its intrinsic ability of undistinguished direct and indirect positive effect on plant growth [20] [21]. Collectively, soil application of HA modify aggregation, aeration, and permeability of soil as well as increase its water holding capacity. Apart from that HA increases microbial activity, consequently increases the rate of organic matter mineralization and solubilization. This further enhances the availability of macro and micro nutrients to meet the demand of rapid growing crops. The hormonal activity of HA also regulates endogenous hormonal mechanism [20]-[22]. Similar results were reported by Ashraf et al. [23] who found that soaking of seeds in $0.005 \%$ aqueous humate followed by spraying of humate solution significantly increased pods plant ${ }^{-1}$ in mungbean. Our results are also in line with that of Shuixiu and Ruizhen [24] who reported that KOMIX, a HA-containing organic fertilizer significantly increased number of pods plant ${ }^{-1}$ in spring soybean. The HA amendment in soil enhanced the water holding capacity and 
Table 1. Pods/plant, grains/pod, thousand grain weights, grain yield and biological yield as affected by humic acid (HA) application methods in mungbean.

\begin{tabular}{|c|c|c|c|c|c|}
\hline Treatments & Pods plant ${ }^{-1}$ & Grains pod $^{-1}$ & $\begin{array}{l}1000 \text { grain weights } \\
\text { (g) }\end{array}$ & $\begin{array}{l}\text { Grain yield } \\
\left(\mathrm{kg} \cdot \mathrm{ha}^{-1}\right)\end{array}$ & $\begin{array}{l}\text { Biological yield } \\
\left(\mathrm{kg} \cdot \mathrm{ha}^{-1}\right)\end{array}$ \\
\hline Dry seed & $13.0^{\mathrm{f}}$ & $9.4^{\mathrm{b}}$ & $40.9^{\mathrm{d}}$ & $550^{\mathrm{c}}$ & 3325 \\
\hline Water soaked & $18.1^{\text {cde }}$ & $10.7^{\mathrm{a}}$ & $43.1^{\mathrm{bcd}}$ & $973^{\mathrm{ab}}$ & 4480 \\
\hline $\begin{array}{l}\text { Seed priming in } \\
0.5 \% \text { HA solution }\end{array}$ & $15.7^{\mathrm{ef}}$ & $11.0^{\mathrm{a}}$ & $43.3^{\mathrm{bcd}}$ & $805^{\mathrm{bc}}$ & 3625 \\
\hline $\begin{array}{l}\text { Seed priming in } \\
1 \% \text { HA solution }\end{array}$ & $16.8^{\text {de }}$ & $10.8^{\mathrm{a}}$ & $44.9^{\mathrm{abcd}}$ & $820^{\mathrm{ab}}$ & 3825 \\
\hline $\begin{array}{l}\text { Seed priming in } \\
1.5 \% \text { HA solution }\end{array}$ & $16.6^{\mathrm{de}}$ & $11.7^{\mathrm{a}}$ & $46.6^{\mathrm{abc}}$ & $803^{\mathrm{bc}}$ & 3240 \\
\hline $\begin{array}{l}\text { Seed priming in } \\
2 \% \text { HA solution }\end{array}$ & $19.8^{\text {bcd }}$ & $11.0^{\mathrm{a}}$ & $43.6^{\mathrm{bcd}}$ & $843^{\mathrm{ab}}$ & 3875 \\
\hline $\begin{array}{l}\text { Soil application } \\
\text { @ } 1 \mathrm{~kg} \cdot \mathrm{ha}^{-1} \mathrm{HA}\end{array}$ & $21.2^{\mathrm{bc}}$ & $11.3^{\mathrm{a}}$ & $42.8^{\mathrm{cd}}$ & $883^{\mathrm{ab}}$ & 3875 \\
\hline $\begin{array}{l}\text { Soil application } \\
\text { @ } 2 \mathrm{~kg} \cdot \mathrm{ha}^{-1} \mathrm{HA}\end{array}$ & $22.2^{\mathrm{ab}}$ & $11.0^{\mathrm{a}}$ & $48.5^{\mathrm{a}}$ & $1058^{\mathrm{ab}}$ & 4875 \\
\hline $\begin{array}{l}\text { Soil application } \\
\text { @ } 3 \mathrm{~kg} \cdot \mathrm{ha}^{-1} \mathrm{HA}\end{array}$ & $25.3^{\mathrm{a}}$ & $11.6^{\mathrm{a}}$ & $49.4^{\mathrm{a}}$ & $1085^{\mathrm{a}}$ & 4575 \\
\hline $\begin{array}{c}\text { Foliar Spray of } \\
0.01 \% \text { HA solution }\end{array}$ & $21.8^{\mathrm{ab}}$ & $11.2^{\mathrm{a}}$ & $46.2^{\mathrm{abc}}$ & $833^{\mathrm{ab}}$ & 4500 \\
\hline $\begin{array}{c}\text { Foliar Spray of } \\
0.05 \% \text { HA solution }\end{array}$ & $22.9^{\mathrm{ab}}$ & $11.1^{\mathrm{a}}$ & $47.9^{\mathrm{ab}}$ & $884^{\mathrm{ab}}$ & 4600 \\
\hline $\begin{array}{c}\text { Foliar Spray of } \\
0.1 \% \text { HA solution }\end{array}$ & $22.9^{\mathrm{ab}}$ & $11.1^{\mathrm{a}}$ & $46.9^{\mathrm{abc}}$ & $870^{\mathrm{ab}}$ & 4355 \\
\hline LSD $\leq 0.05$ & 3.51 & 1.14 & 4.85 & 267 & ns \\
\hline
\end{tabular}

Means in the same column followed by different superscripts' letters are significantly different from one another at $5 \%$ level of probability. ns: Non-significant.

Table 2. Planned mean comparisons for pods/plant, grains/pod, thousand grain weights, grain yield and biological yield as affected by humic acid (HA) application methods in mungbean.

\begin{tabular}{|c|c|c|c|c|c|}
\hline \multicolumn{6}{|c|}{ Planned mean comparison } \\
\hline Treatment & Pods/plant & Grains/pod & $\begin{array}{l}1000 \text { grain weights } \\
\text { (g) }\end{array}$ & $\begin{array}{l}\text { Grain yield } \\
\left(\mathrm{kg} \cdot \mathrm{ha}^{-1}\right)\end{array}$ & $\begin{array}{l}\text { Biological yield } \\
\left(\mathrm{kg} \cdot \mathrm{ha}^{-1}\right)\end{array}$ \\
\hline Control vs. & $13.0^{* *}$ & $9.0^{* *}$ & $41^{* *}$ & $550^{* *}$ & $3325^{* *}$ \\
\hline Rest & 20.3 & 11.1 & 45.7 & 896 & 4166 \\
\hline Control vs. & $13.0^{* *}$ & $9.4^{* *}$ & $40.9^{* *}$ & $550^{* *}$ & $3325^{* *}$ \\
\hline Water & 18.1 & 10.7 & 43.1 & 973 & 4480 \\
\hline Seed priming vs. & $17.2^{* *}$ & $11.1^{\mathrm{ns}}$ & $44.6^{\mathrm{ns}}$ & $818^{*}$ & $3641^{*}$ \\
\hline Foliar spray & 22.5 & 11.1 & 47.0 & 862 & 4485 \\
\hline Seed priming vs. & $17.2^{* *}$ & $11.1^{\mathrm{ns}}$ & $44.6^{\mathrm{ns}}$ & $818^{\mathrm{ns}}$ & $3641^{*}$ \\
\hline Soil application & 22.9 & 11.3 & 46.9 & 1009 & 4442 \\
\hline Foliar spray vs. & $22.5^{\mathrm{ns}}$ & $11.1^{\mathrm{ns}}$ & $47.0^{\mathrm{ns}}$ & $862^{\mathrm{ns}}$ & $4485^{\mathrm{ns}}$ \\
\hline Soil application & 22.9 & 11.3 & 46.9 & 1009 & 4442 \\
\hline
\end{tabular}

${ }^{* *}$ and ${ }^{*}=$ Significant at $1 \%$ and $5 \%$ level of probability, respectively. ns = non significant. 
this property was exploited by Almarshadi and Ismail, [25] under dry land conditions. Our results may also coincide with their experiment as they reported that higher moisture regime of soil due to HA increased the number of tillers in barley.

\subsection{Grains Pod-1}

Statistical analysis of the data indicated that HA application methods significantly affected grains pod ${ }^{-1}$. Application of HA in any form produced enhanced and statistically similar grains $\operatorname{pod}^{-1}$ as compared to control. Highest number of grains pod ${ }^{-1}$ was produced by HA applied at rate of $3 \mathrm{~kg} \cdot \mathrm{ha}^{-1}$ followed by seed primed in $1.5 \%$ HA solution (11.7), which were at par with each other. Lowest number of grains $\operatorname{pod}^{-1}(9.4)$ was produced by seed soaked in water (Table 1 ).

Planned mean comparison suggested that the differences between control vs. rest and control vs. water soaked were significant for grain $\operatorname{pod}^{-1}$, while all other comparisons were not significant (Table 2). Dry seed produced lower number of grains pod ${ }^{-1}$ as compared to the mean of rest of the treatments and water soaked seed.

Higher number of grains pod $^{-1}$ may be due to the indirect positive effect of HA on chlorophyll content. The increase in chlorophyll content promotes photosynthetic activities which, in turn, diverts more photo-assimilates towards higher number of sinks [22]. This prominent effect is reported in most of the crop species like mustard, Brassica raya, aerobic rice, wheat [21] [26]-[28]. The HA application shows its beneficial effect on number of grains pod $^{-1}$ either applied alone or in combined application with full recommended dose of macronutrient. The same was recently reported by Vanitha and Mohandass, [28], they got highest filled grain percentage by HA application with recommended full nutrient dose under subsurface irrigation in aerobic rice. Almarshadi and Ismail, [25] also reported the significant effect on number of grains/spike in dry land soil amendment with HA. Furthermore, Our result are in conformity with Atak and Kaya [29] and Sharif et al. [30] who reported higher number of grains ear ${ }^{-1}$ in wheat and maize with soil application of HA as compared to control. Our results are also in line with Ashraf et al. [23] who reported that soaking of seeds in $0.005 \%$ aqueous humate followed by spraying of humate solution resulted in higher grain weight as compared to dry seed in spring soybean.

\subsection{Thousand Grain Weights}

Data regarding thousand grain weights and their planned mean comparison are presented in Table 1 and Table 2, respectively. Perusal of the data indicated that HA application methods significantly affected thousand grain weights. Soil application of HA at the rate of $3 \mathrm{~kg} \cdot \mathrm{ha}^{-1}$ resulted in greater grain weight followed by soil application of $\mathrm{HA}$ at the rate of $2 \mathrm{~kg} \cdot \mathrm{ha}^{-1}$. Lowest thousand grain weights were produced by dry seed. Planned mean comparison revealed that the differences between control vs. rest and control vs. water was significant for thousand grain weights while all other comparisons were not significant. Dry seed produced lower thousand grain weights as compared to the rest of the treatments and water soaked seed.

Many authors [21] [28] [31] have reported the greater influence of HA on root growth and establishment. Higher root length in response to HA application fetch increases uptake of macro and micronutrients. The heavier grain weight of mungbean treated with soil application of HA showed the improvement of nutrient availability of soil and its effect on plant growth [21] [32]. Humic acid enhances the uptake and accumulation of nutrients especially $\mathrm{N}$ by easing the permeability of cell membrane [21] [31]. Similarly, Solaiman et al. [33] attributed the significantly higher thousand grain weights and other plant growth parameters in chickpea to the application of nitrogen. The higher uptake of other macro and micro nutrients due to HA included phosphorus, potassium, calcium, magnesium, iron, and zinc [21] [31]. This is also in line with khan et al. [32], and they observed maximum 1000-grain weight in plots treated with $3 \mathrm{~kg} \cdot \mathrm{ha}^{-1} \mathrm{HA}$ with half of the recommended dose in wheat. The results are in line with Sharif et al. [20] and Atak and Kaya [29] who reported heavier grains in wheat and maize by HA soil application as compared to control treatment. Similarly, Thenmozhi et al. [34] reported heavier 100 kernal weight in groundnut with soil HA application at the rate $10 \mathrm{~kg} \cdot \mathrm{ha}^{-1}$.

\subsection{Grain Yield $\left({\left.\mathrm{kg} \cdot h \mathrm{~h}^{-1}\right)}^{-1}\right.$}

Perusal of the data indicated that HA application methods significantly affected grain yield. Highest grain yield was produced by HA soil application at the rate of $3 \mathrm{~kg} \cdot \mathrm{ha}^{-1}$, followed by HA soil application at the rate of 2 $\mathrm{kg} \cdot \mathrm{ha}^{-1}$ (Table 1). Dry seed produced the lowest grain yield. Planned mean comparison revealed that the differ- 
ences between control vs. rest and control vs. water soaked were significant for grain yield, while other comparisons were not significant. Dry seed produced the lowest grain yield as compared to the mean of rest of treatments and water soaked seed (Table 2).

The higher grain yield due to HA application in this research corroborates the findings of Khan et al. [32]; Vanitha and Mohandass, [28]; Thenmozhi et al. [34]; David and Samule, [26]; Albayrak, [27]; Almarshadi and Ismail, [25]. These authors suggested the use of HA due to its beneficial effect on grain yield in several crop species like wheat, aerobic rice, groundnut, mustered, Brassica raya, and barley. Moreover, the higher grain yield in plots applied with $3 \mathrm{~kg} \cdot h a \cdot \mathrm{ha}^{-1}$ may be due to higher yield components in the same plots. The results further verify those of Sarir et al. [35] and Sharif et al. [30], who reported that HA alone increased the grain yield by $72 \%$ over the control. Similarly Shuixiu and Ruizhen [24] reported the HA application to soil increased the yield of spring soybean.

\subsection{Biological Yield $\left(\mathrm{kg} \cdot \mathrm{ha}^{-1}\right)$}

Humic acid application methods did not significantly affect biological yield (Table 1). Planned mean comparison indicated that the differences between control vs. rest and control vs. water soaked were significant for biological yield, while all other comparisons were not significant (Table 2). Dry seed resulted in lower biological yield as compared to the mean of rest of treatments and water soaked seed. The results are not in line with those of Sarir et al. [35] and Sharif et al. [30] who reported that HA application increased biological yield up to 23\% and 25\%, respectively. Similar results are also reported by Ashraf et al. [23] who observed significant effect on total dry matter of mungbean with application HA as soil applied.

\section{Conclusion}

Humic acid (HA) is a vital constituent and an intimate part of soil organic structure. It has been used by many scientists, agronomists and farmers for improving soil conditions and plant growth. Humic acid application at the rate of $3 \mathrm{~kg} \cdot \mathrm{ha}^{-1}$ resulted in a higher number of pods plant ${ }^{-1}$, thousand grain weights and grain yield, however it was statistically similar to the treatments where humic acid was soil applied at rate of 1 and $2 \mathrm{~kg} \cdot \mathrm{ha}^{-1}$, seed priming with (water soaked), $0 \%, 1 \%, 2 \%$ of HA solution and foliar spray with $0.01 \%, 0.05 \%$ and $0.1 \%$ of HA solution. It is concluded that humic acid application in all the three methods significantly enhances grain yield and yield components of mungbean.

\section{Acknowledgements}

The present research work was funded by the Eco-Innovation Project, Korean Government's R\&D program on Environmental Technology and Development, Republic of Korea.

\section{References}

[1] Mondal, M.M.A., Puteh, A.B., Malek, M.A., Ismail, M.R., Rafii, M.Y. and Latif, M.A. (2012) Seed Yield of Mungbean (Vigna radiata (L.) Wilczek) in Relation to Growth and Developmental Aspects. Scientific World Journal, 212, Article ID: 425168. http://dx.doi.org/10.1100/2012/425168

[2] Malik, B.A. (1994) Grain Legumes. In: Nazir, S., Bashir, E. and Bantel, R., Eds., Crop Production, National Book Foundation, Islamabad, 277-228.

[3] Shanmugasundaram, S., Keatinge, J.D.H. and Hughes, J. (2009) Counting on Beans: Mungbean Improvement in Asia. In: Spielman, D.J. and Pandya-Lorch, R., Eds., Millions Fed: Proven Successes in Agricultural Development, IFPRI, Washington DC. http://www.ifpri.org/sites/default/files/publications/oc64ch15.pdf

[4] Fagbenro, J.A. and Agboola, A.A. (1993) Effect of Different Levels of Humic ACID on the Growth and Nutrient Uptake of Teak Seedlings. Journal of Plant Nutrition, 16, 1465-1483. http://dx.doi.org/10.1080/01904169309364627

[5] O’Donnell, R.W. (1973) The Auxin-Like Effects of Humic Preparation from Leonardite. Soil Science, 116, $106-112$. http://dx.doi.org/10.1097/00010694-197308000-00007

[6] Lee, Y.S. and Bartlett, R.J. (1976) Stimulation of Plant Growth by Humic Substances. Soil Science Society of America Journal, 40, 876-879.

[7] Khattak, R.A. and Muhammad, D. (2006) Effect of Pre-Sowing Seed Treatments with Humic Acid on Seedling Growth and Nutrient Uptake. Internship Report, Department of Soil and Environmental Science, NWFP Agriculture 
University, Peshawar.

[8] Sharif, M., Khattak, R.A. and Sarir, M.S. (2003) Residual Effect of Humic Acid and Chemical Fertilizers on Maize Yield and Nutrient Accumulation. Sarhad Journal of Agriculture, 19, 543-550.

[9] Kaya, M. and Khawar, K.M. (2005) Effect of Pre-Sowing Seed Treatment with Zinc and Foliar Spray of Humic Acids on Yield of Common Bean. International Journal of Agriculture and Biology, 7, 875-878.

[10] Savithri, P., Perumal, R. and Nagarajan, R. (1999) Soil and Crop Management Technologies for Enhancing Rice Production under Micronutrient Constraints. Nutrient Cycling in Agroecosystems, 53, 83-92. http://dx.doi.org/10.1023/A:1009753729599

[11] Wilhelm, N.S., Graham, R.D. and Rovira, A.D. (1988) Application of Different Sources of Manganese Sulphate Decreases Take-All of Wheat Grown in a Manganese Deficient Soil. Australian Journal of Agricultural Research, 39, 1-10. http://dx.doi.org/10.1071/AR9880001

[12] Harris, D., Joshi, A., Khan, P.A., Gothkar, P. and Sodhi, P.S. (1999) On-Farm Seed Priming in Semi-Arid Agriculture: Development and Evaluation in Maize, Rice and Chickpea in India Using Participatory Methods. Experimental Agriculture, 35, 15-29. http://dx.doi.org/10.1017/S0014479799001027

[13] Khalid, B.Y. and Malik, N.S.A. (1982) Pre-Sowing Soaking of Wheat Seeds in Copper and Manganese Solutions. Communications in Soil Science and Plant Analysis, 13, 981-986. http://dx.doi.org/10.1080/00103628209367326

[14] Roberts, W.O. (1948) Prevention of Mineral Deficiency by Soaking Seed in Nutrient Solution. Journal of Agricultural Science, 38, 458-468. http://dx.doi.org/10.1017/S0021859600006250

[15] Harris, D., Rashid, A., Miraj, G., Arif, M. and Shah, H. (2007) “On-Farm” Seed Priming with Zinc Sulphate Solution-A Cost-Effective Way to Increase the Maize Yields of Resource-Poor Farmers. Field Crops Research, 102, 119-127. http://dx.doi.org/10.1016/j.fcr.2007.03.005

[16] Bhatti, A.U. (2002) Soil Fertility Status of Malakandher Farm. Soil Bulletin 6, Department of Soil and Environmental Science, NWFP Agricultural University, Peshawar.

[17] Tariq, M., Khan, M.A. and Perveen, S. (2002) Response of Maize to Applied Soil Zinc. Asian Journal of Plant Sciences, 1, 476-477. http://dx.doi.org/10.3923/ajps.2002.476.477

[18] Sadiq, M.S., Sarwar, G. and Khattak, G.S.S. (1999) NIAB MUNG 92: A High Yielding and Short Duration Mungbean Variety. Mutation Breeding Newsletter, 44, 14-15.

[19] Steel, R.G.D. and Torrie, J.H. (1980) Principles and Procedures of Statistics. 2nd Edition, McGraw Hill, New York.

[20] Trevisan, S., Francioso, O., Quaggiotti, S. and Nardi, S. (2010) Humic Substances Biological Activity at the Plant-Soil Interface, from Environmental Aspects to Molecular Factors. Plant Signaling \& Behavior, 5, 635-643. http://dx.doi.org/10.4161/psb.5.6.11211

[21] Tahir, M.M., Khurshid, M., Khan, M.Z., Abbasi, M.K. and Kazmi, M.H. (2011) Lignite-Derived Humic Acid Effect on Growth of Wheat Plants in Different Soils. Pedosphere, 21, 124-131. http://dx.doi.org/10.1016/S1002-0160(10)60087-2

[22] Nardi, S., Pizzeghello, D., Muscolo, A. and Vianello, A. (2002) Physiological Effects of Humic Substances on Higher Plants. Soil Biology and Biochemistry, 34, 1527-1536. http://dx.doi.org/10.1016/S0038-0717(02)00174-8

[23] Ashraf, M., Nasir, S. and Sarfaraz, T.S. (2005) Biological Effect of Bio-Fertilizer Humic Acid on Mungbeans. International Journal of Biology and Biotechnology, 2, 737-739.

[24] Shuixiu, H. and Ruizhen, W. (2001) A Study on the Effect of KOMIX, Humic Acid-Containing Organic Fertilizer, on Spring Soybean. Acta Agriculturae Universitatis Jiangxiensis, 23, 463-466.

[25] Almarshadi, M.S. and Ismail, S.M. (2014) Barley Growth and Productivity as Affected by Soil Amendments under Fully and Minimum Irrigation Conditions in Saudi Arabia. Life Science Journal, 11, 223-230.

[26] David, R.A. and Samuel, M. (2002) Plant Growth Stimulation of Lignite Humic Acid. Part-II. Effect of Lignite Derived Ammonium Humate on Mustard (Brassica juncea L.) Using Different Levels of Phosphate Fertilizer. Pakistan Council of Scientific and Industrial Research, 45, 273-276.

[27] Albayrak, S.C. (2005) Effects of Different Levels and Application Times of Humic Acid on Root and Leaf Yield and Yield Components of Forage Turnip (Brassica rapa L.). Journal of Agronomy, 4, 130-133. http://dx.doi.org/10.3923/ja.2005.130.133

[28] Vanitha, K. and Mohandass, S. (2014) Effect of Humic Acid on Plant Growth Characters and Grain Yield of Drip Fertigated Aerobic Rice (Oryza Sativa L.). The Bioscan, 9, 45-50.

[29] Atak, M. and Kaya, M. (2004) Effects of Zinc and Humic Acid Applications on Yield and Yield Components of Durum Wheat. Anadolu, 14, 49-66.

[30] Sharif, M., Ahmad, M., Sarir, M.S. and Khattak, R.A. (2004) Effect of Organic and Inorganic Fertilizers on the Yield 
and Yield Components of Maize. Pakistan Journal of Agriculture, 20, 11-16.

[31] Nikbakht, A., Kafi, M., Babalar, M., Xia, Y.P., Luo, A. and Etemadi, N. (2008) Effect of Humic Acid on Plant Growth, Nutrient Uptake, and Postharvest Life of Gerbera. Journal of Plant Nutrition, 31, 2155-2167. http://dx.doi.org/10.1080/01904160802462819

[32] Khan, R.U., Rashid, A., Khan, M.S. and Ozturk, E. (2010) Impact of Humic Acid and Chemical Fertilizer Application on Growth and Grain Yield of Rainfed Wheat (Triticum aestivum L.). Pakistan Journal of Agricultural Research, 23, 113-121.

[33] Solaiman, A.R.M., Hossain, D. and Rabbani, M.G. (2007) Influence of Rhizobium Inoculant and Mineral Nitrogen on Some Chickpea Varieties. Bangladesh Journal of Microbiology, 24, 146-150.

[34] Thenmozhi, S., Natarajan, S. and Selvakumari, G. (2004) Effect of Humic Acid on Quality Parameters of Groundnut. Crop Research, 27, 210-213.

[35] Sarir, M.S., Akhlaq, M., Zeb, A. and Sharif, M. (2005) Comparison of Various Organic Manures with or without Chemical Fertilizers on the Yield and Components of Maize. Sarhad Journal of Agriculture, 21, 237-245. 
Scientific Research Publishing (SCIRP) is one of the largest Open Access journal publishers. It is currently publishing more than 200 open access, online, peer-reviewed journals covering a wide range of academic disciplines. SCIRP serves the worldwide academic communities and contributes to the progress and application of science with its publication.

Other selected journals from SCIRP are listed as below. Submit your manuscript to us via either submit@scirp.org or Online Submission Portal.
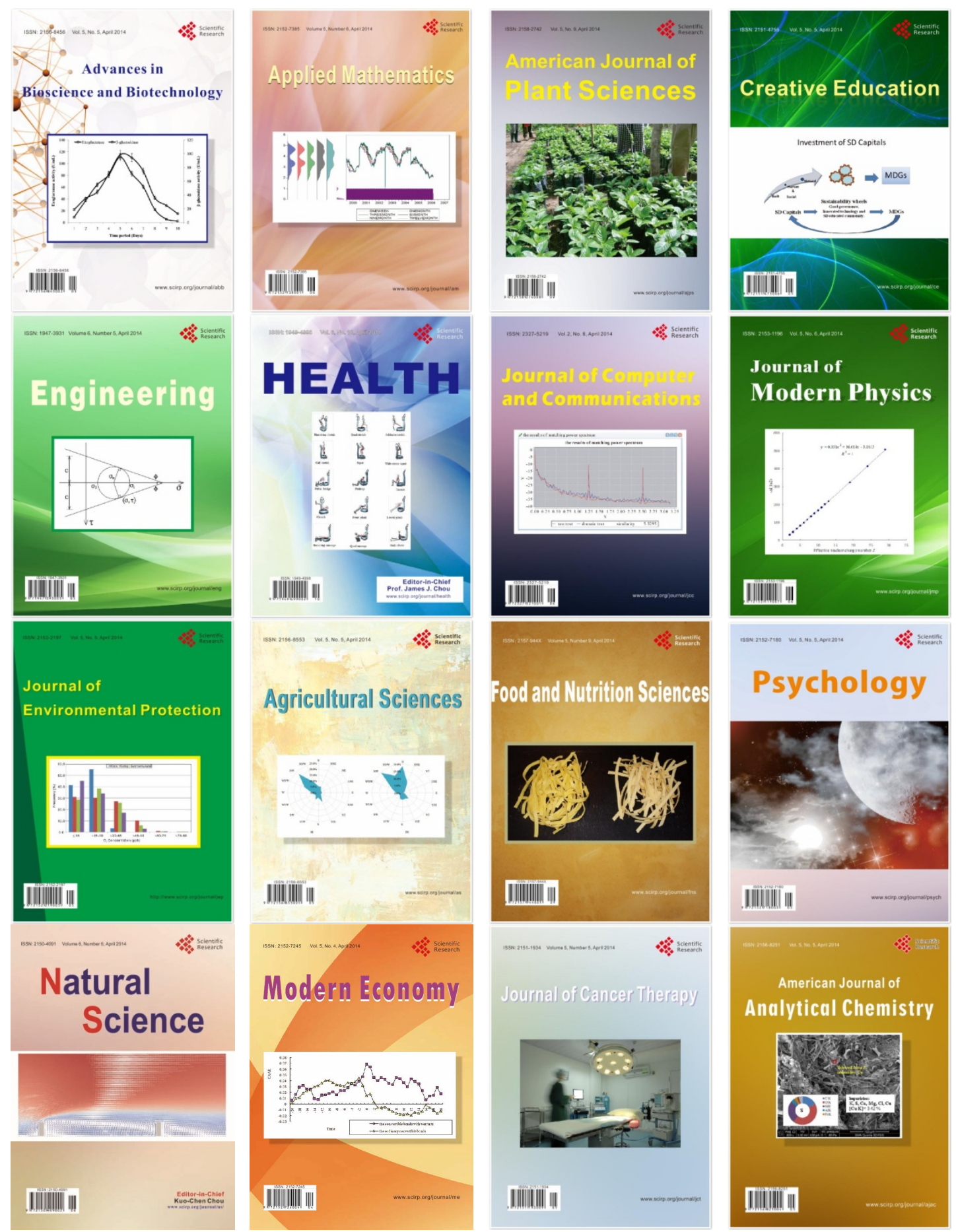